\title{
The importance of symbolism in the development of algebra
}

\author{
Silvio Maracchia
}

Published online: 15 October 2013

(C) Centro P.RI.ST.EM, Università Commerciale Luigi Bocconi 2013

\begin{abstract}
This article examines some of the developments in arithmetic and algebraic symbolism (the equal sign, plus and minus signs, exponents of an unknown) which made possible a noteworthy brevity in exposition and consequently greater ease of learning. Light is also shed on the contribution of symbolism to the development of mathematics, particularly of algebra, by means of its detachment from geometry and the inductive development that this made possible, for example, in the natural extension of the degrees of an equation.
\end{abstract}

Keywords Symbolism - Mathematical symbols ·

Algebra · Rafael Bombelli · Nicolò Tartaglia ·

Nicolas Chuquet · Francesco Galigai · Rene

Descartes · François Viète

\section{Introduction}

One of the tendencies of mankind has always been that of attempting to dominate the environment-any kind of environment - in order to exploit it to the maximum. One way to grapple with this need is to render the environment itself accessible by schematising it to the greatest possible extent to facilitate comprehension and therefore exploitation. There are an infinite number of examples of this in every human expression, both practical and theoretical, from the possibility of understanding and schematising the characteristics of the animal and vegetable kingdoms useful for survival to the simplification of written and oral communication. For example, identifying the principal

S. Maracchia $(\square)$

Via Di Bravetta 588, 00164 Rome, Italy

e-mail: silvio_maracchia@libero.it sounds of the human voice and then successively constructing alphabets led later to writing which, Plato's objections notwithstanding (see Plato, Phaedrus, 275c), made possible the accumulation of notions in all fields along with their corresponding developments.

\section{Giuseppe Peano and symbolism}

Very early on in mathematics, symbolism would reveal itself to be essential in all branches. Although we must proceed by example (since, general considerations aside, it is precisely the particular cases that provide indications and explanations of what has been said), as a bridge between the examples we will use the opening words of the Prefatione of the Formulario Mathematico by Giuseppe Peano (1858-1932). Peano used the latino sine flexione in writing the fifth edition of the Formulario, and we will quote from that, not least to recall the dream of the Italian mathematician from Tetti Galant (an outlying village of Spinetta, in the province of Cuneo), who hoped to find an international language with which mathematics could be expressed across all borders:

Omni progressu de Mathematica responde ad introductione de signos ideographico vel symbolos. Symbolos plus antiquo, hodie adoptato, es cifras Indo-Arabico, o, 1, 2, ..., 9, facto Europaeo in anno 1200 circa. Utilitate plus evidente de cifras es brevitate in scriptura. In secundo loco, cifras reduce vocabulario. Nam numeratione per cifras introduce nullo novo symbolo pro vocabulos "decem, viginti ... centum, mille ..." que es espresso, per symbolos precedente. .... Inter duo systema symbolico, illo que contine minore numero de symbolos es, in generale, 
plus perfecto. Sed utilitate fondamentale de cifras es facilitate in calculos .... Rationes de utilitate nunc exposito pro cifras, subsiste pro omni systema symbolico. Signos,$+-($ a. 1500), $\times($ a. 1600),$=(a$. 1550), > (a. 1650), e, $\pi$ (a. 1700), $\Sigma, \Pi$ (1800), constitue calculo algebrico, et nos non potest concipe Algebra sine signos praecedente. In realitate, magno parte de Algebra elementare es scripto in libros VII, VIII, IX, X de Euclide. Introductione de symbols moderno redde libros de Euclide multo plus breve, elimina enorme vocabulario, mortuo in Algebra moderna; redde theorias precedente plus facile, et permitte constructione de numeroso novo theoria.

(All progress in mathematics corresponds to the introduction of ideographical signs and symbols. The most ancient symbols today in use are the IndoArabic digits, that is, $1,2, \ldots 9$, brought to Europe around the year 1200. The most evident use of digits is their conciseness in writing. In the second place, digits reduce the number of words. For the numbering of the digits introduces no new symbols for the words 'ten, twenty ... one hundred, one thousand ...', which are expressed by the aforementioned symbols. ... Given two systems of symbols, the one that contains a smaller number of symbols is, in general, more perfect. But the fundamental usefulness of digits is their ease in calculations. ... The reasons for the usefulness of digits just stated are true for all systems of symbols. The signs,$+-($ year 1500), $\times$ (year 1600), = (year 1550), > (1650), e, $\pi$ (year 1700), $\Sigma, \Pi$ (1800) constitute algebraic calculation, and we cannot conceive of Algebra without the aforementioned symbols. In reality, the most part of elementary Algebra is written in books VII, VIII, IX and $\mathrm{X}$ of Euclid. The introduction of modern symbols renders Euclid much more concise, eliminates a large number of words, [which are] dead in modern Algebra; it renders earlier theorems easier, and makes possible the construction of numerous new theorems).

Peano does not limit himself to simply stating this, but puts his ideas into action with the Formulario, which in the edition taken into consideration here [18], which even while treating in an exhaustive manner mathematical logic, arithmetic, algebra, geometry, limits, differential and integral calculus and the theory of curves (all of which is enriched by discussions of their history) is, thanks to his symbolism, contained in only 464 pages! (Fig. 1).

In spite of this, except for a very few symbols, Peano's symbolism died with him and were abandoned, along with

\footnotetext{
${ }^{1}$ Peano shows the Greek numeration, which requires many symbols to express not only the first nine numerals but also $10,20, \ldots, 100$, $200, \ldots$
}

his latino sine flexione, even among his proteges when they realised that other symbols and other living languages had been chosen. Nevertheless, an echo of Peano's acuteness and precision can be deduced from a passage from the Autobiography by Bertrand Russell (1872-1970), where he talks about the International Congress of Philosophy held in Paris in 1900:

The Congress was a turning point in my intellectual life, because there I met Peano. I already knew him by name and had seen some of his work, but had not taken the trouble to master his notation. In discussions at the Congress I observed that he was always more precise than anyone else, and that he invariably got the better of any argument upon which he embarked. As the days went by, I decided that this must be owing to his mathematical logic. I therefore got him to give me all his works, and as soon as the Congress was over I retired to Fernhurst to study quietly every word written by him and his disciples. It became clear to me that his notation afforded an instrument of logical analysis such as I had been seeking for years, and that by studying him I was acquiring a new and powerful technique for the work that I had long wanted to do [21, chap. VI, 135-136].

Shortly after the impassioned study of Russell that followed his meeting Peano he produced the famous Principles of Mathematics, a work on which, he says, 'he had already made a number of unsuccessful attempts' [Russell 1967, p. 136].

All of this had already been understood by William Oughtred (1574-1660), who in his Clavis Mathematicae (The Key to Mathematics) of 1631, to which we owe, for example, the symbol $\times$ to indicate multiplication, writes:

The specious and symbolicall manner neither racketh the memory with multiplicity of words, nor chargeth the phantasie with comparing and laying things together, but plainly presenteth to the eye the whole course and processe of every operation and argumentation [17, Preface I, 3-4]. ${ }^{2}$

He goes onto to say that the statements of the theorems can be understood, no longer by only a single people, but by all peoples, no matter what tongue they speak, as long as they know the meaning of the symbols used. It is possible to collocate, we might say, Gottfried Leibniz (1646-1716) between Oughtred and Peano. Like Oughtred and Peano, Leibniz had clearly in mind an idea of the essential

\footnotetext{
2 This quotation is taken from Pycior [19, p. 45]. Note that Florian Cajory [5, p. $187 \mathrm{ff}]$ lists some 150 symbols that provide evidence, in our opinion, as to why they were never adopted.
} 


\section{ALGEBRA.}

\section{$\$ 1$ f \& (functione)}

(\$l-4 contine omni conplemento ad Logies mathematics, occurrente in continustione de Formulario).

* 1 .

- Functio, operatio, correspondentia , es vocabulo identico, ant simile inter se. In lingua commune, omni vocabulo relativo, ut 'patre, fllio,..., indica functio.

Functio es expresso in plure casu per signo que praecede variabile, que me voca signo de eprae-functio , Ita, in c $\log x$, $\sin x>,<\log , \sin$, es signo de prae-functio.

In alios casu, signo de functio seque variabile; me voea illo signo de epost-functio s. Ita in a! (pag. 52), c!, es signo de post-functio.

Nos considera duo classe $a$ et $b$; et nos scribe $u \varepsilon a j b$, et lege c $u$ es signo de post-functione, que transforma omni $a$ in $b$, vel c $u$ es transformatore de $a$ in $b$, vel c $u$ es $a$ ef $b$, , si signo $u$ scripto post omni individuo arbitrario $x$ de classe $a$, produce novo elemento $x u$, que pertine ad classe $b$.

In symbolos:

.0 $a, b \varepsilon C l s . \supset \therefore u \varepsilon a j b=: x \varepsilon a . D^{*} \cdot x u \varepsilon b \quad \mathrm{Df}_{\mathrm{f}}$

Et nos scribe $u \varepsilon$ bfa, et lege $c u$ es signo de prae-functione, que ad omni $a$ fac corresponde aliquo $b$, vel c $u$ es $b$ functione des $a$, si signo $u$ scripto prae omni $a$ produce elemento de classe $b$ :

$\cdot 01 \quad a, b \varepsilon \mathrm{Cls} . \supset \therefore u \varepsilon b f a=: x \varepsilon a . \supset_{x}, u x \varepsilon b \quad \mathrm{Dff}$

Pro brevitate, nos enuntia propositiones super uno solo de duo signo $f$ et $f$.
74

III. $\$ 1 \mathrm{f} \mathrm{f}$

Oper $u$

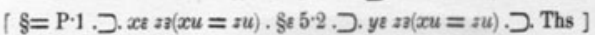

Si duo objecto $x$ et $y$ es aequale inter se, et si super illo nos fac identico operatione $u$, et duo resultatu fi aequale.

Nos c opera per $u$, quando nos transforma aequalitate $x=y$ in $u x=u y$.

$\cdot 2 \quad a, b, c \varepsilon \mathrm{Cls} . u \varepsilon a \mathrm{~g} b . c \supset a . \supset$. $u \varepsilon c y b$

[ Hp.xzc.つ.xza.つ. $x u \varepsilon b: \supset . \mathrm{P}$ ]

-3 $a, b, c \varepsilon$ Cls . $u \varepsilon a \mathrm{\jmath} b . b \supset c . \supset$. $u \varepsilon a \mathrm{~g} c$

[ Hp.つ:xza.つ.xusb.つ.xusc:】. Ths ]

Si $u$ transforma to-s $a$ in $b$, et si $c$ es subelasse de $a$, tune $u$ transforma to-s $c$ in $b$. Si $u$ es semper $a$ ef $b$, et classe $b$ continere in $c$, tune $u$ es $a$ ef $c$.

* $2 \cdot 1+\varepsilon \mathrm{N}_{\omega} \mathrm{N}_{0}$ $[=\$+1 \cdot 2]$

+ s successivo, es operatione que transforma numero in numero. Es propositione primitivo $2 \mathrm{de} \xi+$, seripto per signo $\mathrm{J}$.

$\left.\because 2 \varepsilon \mathrm{Cls} .0 \varepsilon s++\varepsilon s j s . \supset \mathrm{N}_{0}\right]^{s} \quad$ [= Induet ]

$\cdot 3 a \varepsilon \mathrm{N}_{0} \cdot$. $+a \varepsilon \mathrm{N}_{a} \mathrm{~N}_{0} \cdot \times a \varepsilon \mathrm{N}_{0} J \mathrm{~N}_{0} \cdot \Gamma a \varepsilon \mathrm{N}_{a} \mathrm{~N}_{0}$ $\left.\left.-a \varepsilon\left(a+\mathrm{N}_{a}\right) \mathrm{N}_{0}: a \varepsilon \mathrm{N}_{1} \cdot\right] \cdot a \varepsilon\left(a \times \mathrm{N}_{1}\right)\right]_{1} \mathrm{~N}_{1}$

$[=\S+4 \cdot 1 \cdot \S \times 1 \cdot 1, \$ \uparrow 1 \cdot 1 \cdot \S-1 \cdot 1, \S / 1 \cdot 1]$

Si $a$ es numero, tune operationes:

$+a$, * plus $a$, , s additione de $a$, , to adde $a$ s,

$\times a$, s per $a$ s, s to multipliea per $a$ s,

$\mathrm{N}, \mathrm{i}, \mathrm{ad} a, \mathrm{~s}$, to eleva ad potestate $a$,

transforma numero in numero.

Operatione :

$-a$, s minus $a$, \& to subtrahe $a$,

es possibile supra numeros superiore ad $a$, et

$l a, c$ in $a$, , to divide per $a$,

es possibile supra multiplos de $a$.

Plure Auctore moderno claude variabile inter (). Sed parenthesi jam habe in Arithmetica usu determinato, de collega plure elemento, et nos non pote ute illo in novo sensu. In vero, in seriptura $(x)$, litera $x$ non es ligato ad aliquo elemento. Omni Auctore seribe $\log x, \sin x$, et non $\log (x), \sin (x) ; f(x+h)$ et non $f((x+h))$. Lagrange, Abel,... non seribe parenthesi in hoc novo sensu, introducto verso a.1823.

Nota differentia inter $f$ et $f ; f$ es symbolo constante, que nos lege - functione ; $f$ es litera variabile (I § 1 ), que pote repraesenta omni objecto, p. ex. aliquo functione.

Fig. 1 The first two pages of the chapter "Algebra” in Peano's Formulario [18, pp. 73-74]

importance of a symbolism that was efficient and, above all, fruitful. In a moment we will see how Leibniz expresses himself in his De Arte Combinatoria: in contrast to Russell, who intended to express mathematics through the logic that he understood as being more general, ${ }^{3}$ Leibniz wanted so much to express this with mathematics that his cry 'Calculemus! (Let us calculate!) ${ }^{4}$ has become

\footnotetext{
3 Aristotle wrote that any proof is a syllogism, but that the reverse is not true (Analytica Priora 25). Let us bear in mind that in the structure of the syllogism it is possible to find those stages of a hypothetical deductive system (definitions, aximoms, rules of inference, a grammar, a syntax, theorems) that are later found again in Euclid's Elements, but which Aristotle had borrowed from mathematics itself

${ }^{4}$ Among the many bibliographical references to this, we limit ourselves to mentioning Leibniz e la logica simbolica by Massimo Mugnai [15], which is also rich in bibliographical references and includes an anthological section.
}

famous, that is, the possibility of being able to judge the truth of one argumentation with respect to another. It was necessary, Leibniz wrote, to create:

a general method in which all truths of reason would be reduced to a kind of calculation. At the same time this would be a sort of universal language or script, but infinitely different from all those imagined previously, because its symbols and words would direct the reason, and errors - except those of fact - would be mere errors of calculation. It would be very difficult to form or invent this language or characteristic, but very easy to understand it without any dictionaries.

Leibniz, distracted by many other thing he had to do, was not however able to carry out his idea, which he had estimated would take at least five years and require the assistance of various collaborators. 


\section{The history of a few symbols}

Let's go back to the words of Peano quoted above. His description could serve as a guiding thread for the development of this article. First of all regarding the writing of numbers: the practicality of our ten symbols makes it possible to write in a simple way any number whatsoever thanks to the positional system, whose roots are found in the Babylonian system, were then developed by the Indians and later still by the Arabs. This practicality is not just due to the limited number of symbols (the Romans, for example, used fewer symbols, not to mention the binary system) but is essentially a result of the positional system, which makes it easy to carry out operations that would otherwise be quite complicated. ${ }^{5}$

In this regards, I quote a meaningful passage from André Weil's Number Theory:

To guage the difficulty of the problem [of the search for divisors] for some of Fermat's contemporaries, one must remember that, as late as 1640 ... Mersenne $^{6}$ was asking Saint-Martin how to find the number of divisors of 49,000 and their sum without enumerating them one by one; Euclid, and perhaps even the mathematicians around Plato ... might have found this a naive question. Of course, a good algebraic notation is a great help in such matters, indeed even indispensable. ${ }^{7}$

Peano mentions the proofs of Euclid, which modern symbolism renders much shorter. Let us look at just one example, that is, proposition IX, 36 in which Euclid proves that a number obtained as the product of multiplying a sum of a number of powers of 2 (beginning with $2^{0}$, or 1 ), that is, $1+2+2^{2}+2^{3}+2^{4}+\ldots$ that is interrupted when its sum is a prime number, by the last term in the series, is a perfect number. ${ }^{8}$ Recall, for instance, that 28 is a perfect number since $28=1+2+4+7+14$. Now, recalling also that $1+2+2^{2}+2^{3}+2^{4}+\ldots+2^{n-1}=2^{n}-1$, in the case that such a sum is a prime number, Euclid proves

\footnotetext{
5 The binary system also uses the positional technique but in this case even numbers that are not very large have quite a number of digits and their use is not very practical.

${ }^{6}$ Marin Mersenne was a well-known mathematician in his day. As to the decomposition of 49,000 into factors, this is a problem that can be solved today by any junior high school student.

7 The English quotation is taken from [23, p. 59], but I also consulted the Italian edition [22, pp. 46-47] containing an Introduction by Enrico Bombieri, who considered Weil one of the greatest mathematicians who was able to unite rigour with ampiezza di respiro, breadth of thought.

${ }^{8}$ Elements, Prop. IX, 36: "If as many numbers as we please beginning from an unit be set out continuously in double proportion, until the sum of all becomes prime, and if the sum multiplied into the last make some number, the product will be perfect" [10, II, p. 421].
}

that the number $N=\left(2^{n}-1\right) \ldots 2^{n-1}$ is a perfect number. Taking 28 as our example, we take the powers of 2 up to where they are prime, $1+2+2^{2}=7$ and multiply that sum by the last power, $2^{2}=4$, then we have $N=\left(1+2+2^{2}\right) \ldots 2^{2}=7 \ldots 4=28$, a perfect number. Well then, with our symbolism, proving that the sum of the divisors of the number $N=\left(2^{n}-1\right) \ldots 2^{n-1}$ (with $\left(2^{n}-1\right)$ the prime number) is equal to the number itself and is immediate, ${ }^{9}$ while Euclid's brilliant proof is rather long; Mersenne's proof would probably have been equally long, if not longer.

Peano also cites the years in which some of the mathematical symbols were used for the first time. We have to say that the exact dates are not always known, in part because it is not easy to establish, especially before the invention of the printing press, when and by whom they were used. $^{10}$

Thus, the history of mathematical symbolism goes from the moment when a given operation was given a particular name, one usually taken from common vocabulary (rhetorical form), to its increasing detachment from its initial name through use of an appropriate distinguishing mark (literal form) to, finally, the use of only the mark (symbolic form). This is the case, for example, of addition, not indicated in pre-Hellenic and Hellenic mathematics except by juxtaposition of the terms, which was also the case in Greek and Roman numeration, except for a few stratagems. Later in the West addition was indicated first with $e t$, with plus, then with $p$ and only at the end with the symbol we use today, + .

The development of the symbol for subtraction was almost analogous. However, to indicate subtraction Diophantus of Alexandria (ca. third century A.D.) used a particular sign that was rather like an upside-down $\Psi: \mathbb{}$. Later the word minus was used, and then simply the letter $m$ and, finally, the sign we use today, - .

The origins of the signs + and - that we use are obscure, but they are found in Germany in various manuscripts from around the end of the fifteenth century; they appear for the first time in print by Johannes Widmann in his Behende und hubsche Rechnung ('Mercantile Arithmetic') of $1489 .^{11}$

\footnotetext{
9 The divisors of $N$ sono $1 ; 2 ; 2^{2} ; 2^{3} ; \ldots ; 2^{n-1} ; 1\left(2^{n}-1\right) ; 2\left(2^{n}-1\right)$; $2^{2}\left(2^{n}-1\right) ; 2^{3}\left(2^{n}-1\right) ; \ldots ; 2^{n-2}\left(2^{n}-1\right)$, the sum of which is $1+2+2^{2}+2^{3}+2^{4}+\ldots+2^{n-1}+\left(2^{n}-1\right)\left(1+2+2^{2}+2^{3}\right.$ $\left.+2^{4}+\ldots+2^{n-2}\right)=\left(2^{n}-1\right)+\left(2^{n}-1\right)\left(2^{n-1}-1\right)=\left(2^{n}-1\right) 2^{n-1}=N$. ${ }^{10}$ Florian Cajori observed: "Often the choice of a particular symbol was due to a special configuration of circumstances (large group of pupils, friendships, popularity of a certain book, translation of a text) other than those of intrinsic merit of the symbol" [5, pp. 337-338].

${ }^{11}$ In his documented Histoire, Guglielmo Libri [12, p. 46] attributed the invention of the symbols + and - to Leonardo da Vinci; the reference he gives is MSS, Vol. A, f. 19.
} 
As a last example, let's look at the equal sign (=) and its essential role in the development of algebra in setting the terms of an equation equal to zero. The operation, on closer inspection, liberates algebra from geometry, rendering it completely autonomous. In fact, even in simple equations such as $3 x+5=0$ and $5 x^{2}+x+4=0$, it is no longer necessary to conceive the first term as constituted by rectangles or squares as was usually done at the beginning of algebra, which imposed a limitation on algebra itself. ${ }^{12}$ Further, the possibility of having all terms in a single expression, be they positive or negative, overcomes the obstacle of having to consider various special cases, thus unifying the analysis of the equations. Joseph Needham writes:

Perhaps the most important of all symbols, that which made equations possible, was the sign $=$ for equality. Various marks for this had been used in Babylonia and Egypt [16, p. 114]. ${ }^{13}$

But our intention here is to speak about the symbol $=$ and of the equality to zero. That equality is attributed to Thomas Harriot (1560-1621) (see his Artis analitycae praxis of 1631 in which are also found the symbols $>$ and $<$ ), even though it had already been considered earlier by Rafael Bombelli (1526-1572) in his manuscript; in his printed work as well, in treating an equation, he writes agguaglisi a zero ('is equal to zero'). ${ }^{14}$

\footnotetext{
${ }^{12}$ Recall that, when he prepared to treat equations of the fourth degree, Cardano, almost as though apologising, wrote: "La sesta cosa da notare [è] che non appena l'uomo sarà giunto a conoscere $i$ Capitoli [sc. Le equazioni] sino a quelli relativi al cubo e sono 19 ne ha quanto basta per ogni caso algebrico, poiché sino al cubo si trova gradazione in natura: infatti vi sono linee, superfici e corpi e le linee corrispondono alle incognite lineari; le superfici ai quadrati; $i$ corpi ai cubi. Se pertanto avremo fornito su queste, notizie sufficienti, sarà noto ciò che è necessario; in verità ciò che aggiungiamo al di là, è per diletto ["ad voluptatem"] e non per compimento di ciò che può trarsi da [tale] studio. Tali Capitoli successivi non esistono veramente in sé ma solo per caso fortuito, se anche ve ne siano [formule] generali". Thus, in his most important work, the Ars Magna of 1545, Cardano [6, p. 222] spoke of having dealt with fourth-degree equations "quasi per estensione ... in ciò che non è lecito in natura". Much earlier Omar Khayyam (1044-1123/24) had expressed himself the same way [14, p. 303], but his work would not become known in the West until the 1851 edition of his Algebra by Franz Woepke.

${ }^{13}$ Note that the equal sign is sometimes implied by 'is', 'gives' and the like. We shall give only one example taken from problem 19 of the Moscow Papyrus (nineteenth century B.C.): Calculate a quantity taken 1 and $1 / 2$ times and added to 4 to make 10 . Other times it is written out $i \sigma o \varsigma_{\text {in }}$ Greek or simply the initial $l$, as well as aequalis, aeq, etc.

14 The equation cited is found in [2, p. 191]. Testifying to the complexity of the search for the origins of mathematical symbols, we recall that Cossali [8, p. 322] saw the equality of a particular equation to zero in a procedure of Cardano's, even though it was not rendered wholly explicit.
}

With regard then to the equal sign, which is also explicit in Bombelli's work, Regiomontanus and Pacioli had previously used a single dash, but in a Chinese book of physics of the sixteenth century appears the equal sign we are familiar with, albeit more elongated [16, p. 144]. That symbol, independently chosen, was rightly attributed to Robert Recorde (1510-1558) in his work entitled The Whetstone of Witte of 1557 , because this was the work that brought it to the attention of the mathematicians. Recorde wrote:

And to avoide the tediouse repetition of these woords : is equal to: I will sette as I do often in woork use, a paire of parallels, or Gemowe lines of one length, thus: because noe 2 thynges can be moare equall. ${ }^{15}$

\section{The unknown and its 'dignities'}

Passing to algebra, it can be observed that an initial nonsymbolism (rhetorical algebra) is followed by the prevalence of geometric symbolism in which the unknown is usually indicated by a line segment, the product of the unknown with a numerical coefficient by a rectangle, and the square of the unknown by a geometrical square. This occurs, for instance, in Babylonian algebra, but these correspondences survived, albeit with various exceptions, up to Cardano. In this way algebra was confined, as we have already seen, to the first dimensions (one or two) with only a few limited sorties into the third dimension, given the greater complexity of solid geometry (see Plato's reproach in Republic 528b-d).

Progress was made when the unknown came to be indicated in an explicit way, detached from geometry, even though the procedures for determining it were often themselves geometric: aha (quantity) in Egypt; the word $\alpha \rho \imath \theta \mu o ́ \varsigma$ (number) in Greek or simply the final $\varsigma$; or the Indian and Arabic words for 'thing'. This last usage was transmitted to the West, such that 'the art of the thing' was sometimes used to refer to algebra. Recall, for instance, the rhymes that Tartaglia wrote to Cardano-Quando ch'el cubo con le cose appresso/se agguaglia a qualche numero discreto-to express $x^{3}+a x=b$, published in Quesiti et inventioni diverse, 1546 (Fig. 2):

These various notations and others used from time to time to indicate subtraction, power or the denominator provide evidence of the search for a way of writing that was not so much symbolic as more rapid (literal algebra). We can in fact only speak of symbolism when, following Peano, the symbols become part of a coherent plan that

\footnotetext{
$\overline{15}$ See [20, p. ix]. However, the symbol = entered into current usage only after it had been accepted and used by Wallis and Newton.
} 


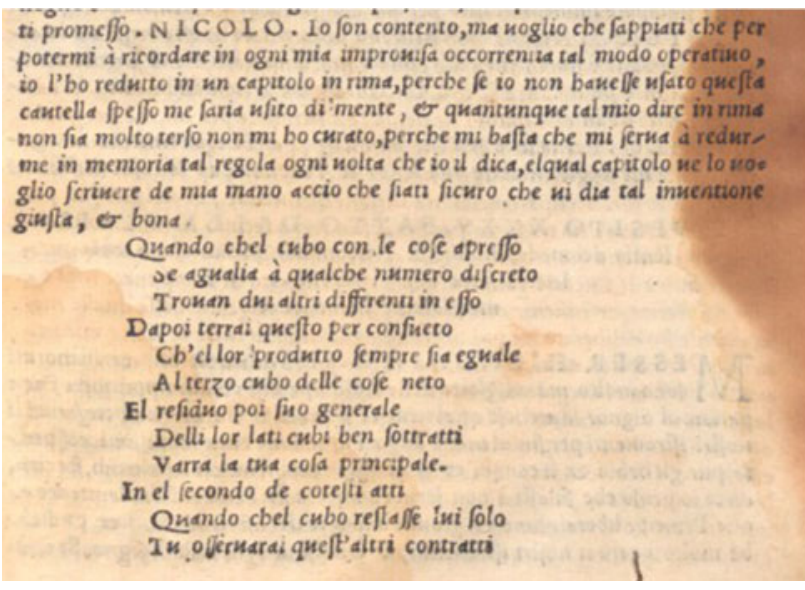

Fig. 2 Nicolò Tartaglia, Questiti et inventioni diverse, Book IX, quesito XXXIIII, p. 124r

makes possible not only faster writing but also the capacity for development, of generalisation of the problems so as to be able to apply them to problems of higher levels. Thus, if we look at the singular symbolism used by in Pratica d'Arithmetica (1521) by the Florentine mathematician Francesco Galigai (ca. 1500-1537), constituted by little squares and rectangles (Fig. 3), we see that it would have been hard for them to have been developed successively.

Let us then consider the 1484 work Triparty by Nicolas Chuquet (1445-1488). According to Gino Loria, the presence of notable Italianisms testify to the certainty of the influence of Italian mathematics, ${ }^{16}$ but, he adds shortly after, "the most remarkable characteristic of this work consists in the fact that here for the first time the exponents make their appearance' [13]. For example, $.10 .^{1}$ stands for $10 x ; .12 .^{2}$ stands for $12 x^{2}$ and, more significantly, $.5 .^{1}$ by $.8 .^{1}$ results in $.40 .^{2}$ (Fig. 4 ).

It is however probable that, with regard to the exponents of the unknowns, the greatest influence is due to the much more widely circulated Algebra by Rafael Bombelli (ca. 1526-1572), in which the unknowns and their corresponding powers alike were set in relation to whole numbers, with a clear indication of how to operate with them. ${ }^{17}$ The awareness shown by Bombelli of how to treat the unknown and its powers (or 'dignities' as Bombelli called them, is shown in an explicit way in the second book of his Algebra, ${ }^{18}$ dedicated to the algebraic solution to equations of the first four degrees.

\footnotetext{
16 This opinion was also expressed by Aristide Marre, the editor of Chuquet's Triparty [7]. However, the opinion was not shared by Jean Itard [11], who instead saw Latinisms.

17 Bombelli's manuscript is found in Codice B. 1569 of the Biblioteca dell'Archiginnasio in Bologna, and was published in 1572. However, the manuscript dates to 1550 according to Bortolotti [4, p. 175]. Ettore Bortolotti has written many articles regarding the use of symbols for the unknown in Bombelli; see in particular [3].
}

\section{OS L I R O \\ Dimoftratione dis figure, le quale Giouanini del Sodô pratica la flua} Arcibra, \& perche in parte terro'el fuoftile le dimoftrero's

\section{LE FIGVRE:}

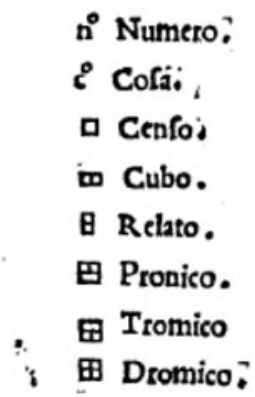

\section{Dichiaratione dille foprascritte figure;}

Fig. 3 The symbolism of Galigai explained, from the 1552 edition of Pratica d'Arithmetica (p. 71v)

As far as regards our topic at hand, we note that, after having defined the unknown as 'so much' in order to distinguish it from the too generic 'thing', Bombelli shows how to treat monomials and polynomials. ${ }^{19}$ Successive to that he places the section Del moltiplicare delle dignità fra loro semplicemente (On multiplying the dignities by each other simply), where he establishes how to write the dignities (see Fig. 5) and their operations. On p. 205 he writes:

Quando si haverà a moltiplicare dignità si sommaranno i numeri delle abbreviature posti di sopra, e di quelli si formarà una abbreviatura di dignità ed il numero che darà disparo a esse dignità si moltiplicarà semplicemente (come si moltiplicano gli altri numeri) ...

(When one has to multiply dignities [i.e., powers] one adds the numbers of the abbreviatures written above, and from those will be formed an abbreviature of dignities and the number that stands below that dignity [i.e., the numerical coefficient] is simply multiplied (as the other numbers are multiplied) ....

The next significant step forward in symbolism occured with François Viète (1540-1603), when the coefficients present in the equations were systematically indicated with

\footnotetext{
18 The first book deals with operations between the powers of numbers and between roots of all kinds, with the successive extension to complex numbers, of which he is the first to give a correct arithmetic.

19 This would be the route subsequently followed in all texts of the algebra of equations; the same thing occurred with algebra as had occurred in geometry after Euclid's Elements, whose exposition became the example followed in later texts.
} 
Fig. 4 Excerpt from Chuquet's Triparty showing his symbols for operations with powers of unknowns [7, p. 160] đ Aussı par ceste maniē qui vouldroit partir 30. m. $1 .^{t}$ par $.1 .^{2}$ plus .1. Il auroit .30. $\overline{\mathrm{m}} \cdot 1^{1}$. partiteur $1 . .^{2} \overline{\mathrm{p}} \cdot 1^{1}$. que lon peult ainsi mettre $\frac{30 \cdot \overline{\mathrm{m}} \cdot 1^{1}}{10^{2} \overline{\mathrm{p}} \cdot 1^{1} \text {. }}$ Or mettons que ceste differance de nombre fust egale ou semblant a..$^{0}$ Il conuiēdroit lune et laultre parties multiplier par la maniere dessusđ et lon

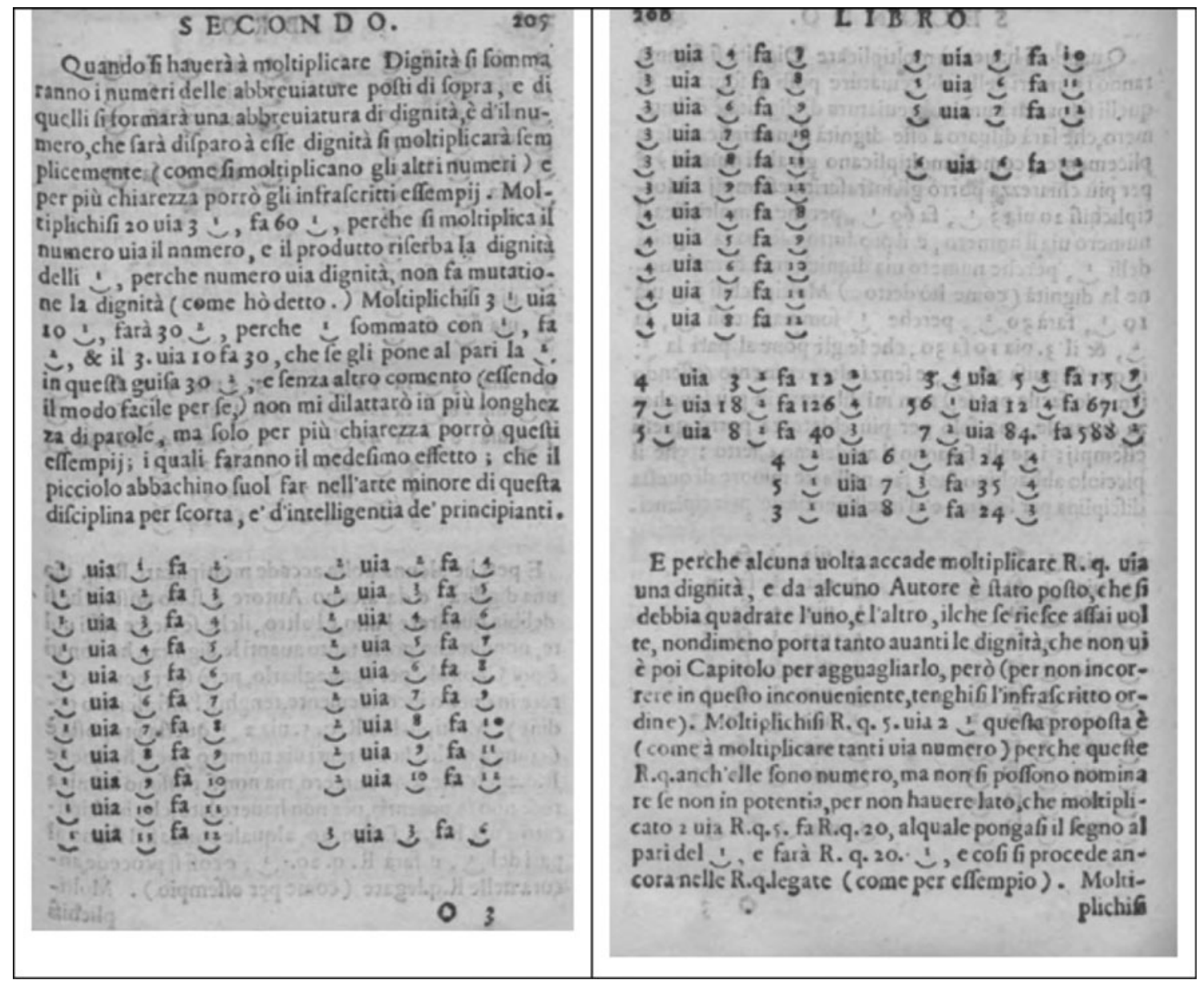

Fig. 5 pp. 205-206 from Rafael Bombelli's Algebra [1]. The analogous page in the 1966 edition of Bombelli's treatise edited by Ettore Bortolotti is found on p. 157

letters ${ }^{20}$ generalising the procedures for their solution and establishing the rules of equality, thus turning algebra into a hypothetical deductive system like geometry. However, Viète's 'law of homogenity', according to which all the terms of an equation (when a corresponding geometry is present) must be of the same dimension, notably fettered the symbolism. It would be his contemporary, René Descartes (1596-1650), whose algebraic symbolism was very close to our own, who detached it from the conditioning of

\footnotetext{
$\overline{20}$ It should be noted that this important step in symbolism had various precedents. For more on this, see [14], chap. 6] dedicated to Viète and Descartes, and in particular § 6.2.7, 'Algebra letterale'.
}

geometry. In fact, perhaps with a nod towards Viéte as well, in his Discourse on Method (1637) Descartes wrote:

Besides, as far as the analysis of the ancients or modern algebra is concerned, and besides that they embrace only matters highly abstract and, to appearance, of no use, the former is so exclusively restricted to the consideration of figures that it can exercise the understanding only on condition of fatiguing the imagination; and, in the latter, there is so complete a subjection to certain rules and formulas that there results an art full of confusion and obscurity calculated to embarass, instead of a science fitted to cultivate the mind [9]. 
Later, after having explained some of the ways he used to write different arithmetic terms, he added meaningfully:

With regard to this I must note that with $\mathrm{a}^{2}$ or $\mathrm{b}^{3}$ or other similar expressions I generally intend only absolutely simple lines, even if I call on them to serve me as terms of algebra, squares, cubes, etc.

\section{Conclusion}

The powers written with whole numbers led logically to the desire to deal with those of degrees greater than three, four and so forth. The use of practical symbols favours this extension, even though remarkable skill, and in some cases, genius, was still required to develop the algebra of today's equations. Indeed, a symbolism that was increasingly concise led almost naturally to what we call today abstract algebra.

We can conclude our brief history by observing that in order to conquer highest summits, in addition to a noteworthy physical preparation and great courage, we also need comfortable, efficient footwear!

Translated from the Italian by Kim Williams

\section{References}

1. Bombelli, R.: L'Algebra. Giovanni Rossi, Bologna (1579)

2. Bombelli, R.: L'Algebra. In: Bortolotti, E. (ed.). Feltrinelli, Milan (1966)

3. Bortolotti, E.: Sulla rappresentazione simbolica della incognita e delle potenze di essa introdotta dal Bombelli. Archivio di Storia della Scienza, vol. VIII, pp. 49-63 (1927) [Rpt. in: Seconda serie di Studi e Ricerche sulla storia della matematica in Italia, Zanichelli, Bologna (1944)]

4. Bortolotti, E.: Algebra nella scuola matematica bolognese del secolo XVI. Periodico di Matematiche (1925)

5. Cajory, F.: A History of Mathematical Notations. Open Court Publishers, London (1928)

6. Cardano, N.: Ars Magna. In: Witmer T. R. (trans.). Dover, New York (1963)

7. Chuquet, N.: La Triparty en les sciences des nombres. In: Marre, A. (ed.) Extrait du Bullettino de Bibliografia e di Storia delle Scienze Matematiche e fisiche, vol. XIII (1880)

8. Cossali, P.: Origine e trasporto in Italia, primi progressi in essa dell'algebra, Tip. Parmense, II (1799)

9. Descartes, R.: Discourse on Method and Meditations on First Philosophy. Renaissance Classics (2012)

10. Euclid.: In: Heath, T. L. (ed.) The Thirteen Books of the Elements, 3 vols. Dover, New York (1956)

11. Itard, J.: Essai d'histoire des Mathématiques. Blanchard, Paris (1984)

12. Libri, G.: Histoire des Sciences Mathematiques en Italie, 4 vols. J. Renouard \& cie, Paris (1840)

13. Loria, G.: Storia della Matematica. Cisalpino-Goliardica, Milan (1982)

14. Maracchia, S.: Storia dell'Algebra, 2nd edn. Liguori, Naples (2008)

15. Mugnai, M.: Leibniz e la logica simbolica. Sansoni, Florence (1973)

16. Needham, J.: Science and Civilisation in China. Mathematics and the Sciences of the Heavens and the Earth, vol. 3. Cambridge University Press, Cambridge (1959)

17. Oughtred, W.: The Key to Mathematicks, New Forged and Filed.... Harper Thomas, London (1647)

18. Peano, G.: Formulario Mathematico (1908). In: Cassina, U. (ed.) Facsimile Reproduction. Cremonese, Rome (1960)

19. Pycior, H. M.: Symbols, Impossible Numbers, and Geometric Entanglements: British Algebra Through the Commentaries on Newton's Universal Arithmetick. Cambridge University Press, Cambridge (2006)

20. Recorde, R.: The Whetstone of Witte (1557), Facsimile edn. TGR Renascent Books, Derby (2013)

21. Russell, B.: Autobiography. Routledge, New York (2010)

22. Weil, A.: Teoria dei Numeri. In: Collo, A. (trans.), Bartocci, C. (eds.). Einaudi, Torino (1993)

23. Weil, A.: Number Theory: An Approach Through History from Hammurapi to Legendre. Birkhäuser, Basel (2007)

\section{Author Biography}

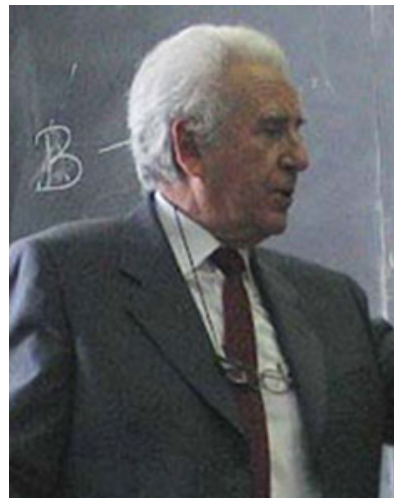

(Liguori, Naples, 2008).
Silvio Maracchia taught history of mathematics for 30 years at the Università di Roma 'La Sapienza'. He is the author of various books and numerous articles of a scientific and didactic nature. He has shared his love for mathematics and its history in over five hundred talks and lectures in Italy and abroad. Noteworthy among his articles and books dedicated to the history of algebra and its symbolism from its origins up to today, is his Storia dell'Algebra 